\title{
CORROSION BEHAVIOR OF Fe-Al LAYERS IN SEAWATER CHARACTERIZED WITH ELECTROCHEMICAL IMPEDANCE SPECTROSCOPY
}

\author{
KARAKTERIZACIJA KOROZIJSKEGA OBNAŠANJA Fe-AI PLASTI \\ V MORSKI VODI Z ELEKTROKEMIČNO IMPEDANČNO \\ SPEKTROSKOPIJO
}

\author{
Ningning Li ${ }^{1,2}$, Guang Chen2 ${ }^{2}$, Xi Chen ${ }^{1}$, Jiajia Yang ${ }^{1}$, Liang Huang ${ }^{1}$ \\ ${ }^{1}$ School of Materials Science and Engineering, North China University of Water Resources and Electric Power, \\ Zhengzhou 450045, P. R. China \\ ${ }^{2}$ MIIT Key Laboratory of Advanced Metallic and Intermetallic Materials Technology, Engineering Research Center of Materials Behavior and \\ Design, Ministry of Education, Nanjing University of Science and Technology, Nanjing 210094, P. R. China
}

Prejem rokopisa - received: 2020-04-09; sprejem za objavo - accepted for publication: 2020-06-08

doi:10.17222/mit.2020.057

\begin{abstract}
The corrosion behavior of Fe-Al layers in artificial seawater was studied using electrochemical impedance spectroscopy (EIS). The layers were previously prepared on a Q235 low-carbon steel surface. Results show that there are two capacitive arcs during the whole immersion of the $\mathrm{Fe}-\mathrm{Al}$ layers, fabricated at $650{ }^{\circ} \mathrm{C}$ and $750{ }^{\circ} \mathrm{C}$. The two capacitive arcs represent two chemical reactions. The Fe-Al layer was the sacrificial anode, used for the cathodic protection. The results illustrate that the Fe-Al layer fabricated at $750^{\circ} \mathrm{C}$ exhibited a better corrosion performance as it was protected by the passive film during the long immersion.

Keywords: Fe-Al layer, electrochemical impedance spectroscopy, corrosion behavior, sacrificial anode
\end{abstract}

Avtorji v članku opisujejo študijo korozijskega obnašanja Fe-Al plasti v umetni morski vodi. Teste so izvajali z elektrokemično impedančno spektroskopijo (EIS). Plasti so predhodno nanesli na površino malo-ogljičnega jekla Q235. Rezultati študije so pokazali, da sta nastala dva kapacitivna obloka pri popolni potopitvi Fe-Al plasti, ki sta bili izdelani pri $650{ }^{\circ} \mathrm{C}$ in $750{ }^{\circ} \mathrm{C}$. Ta dva kapacitivna obloka so pripisali dvema kemičnima reakcijama in Fe-Al plast je igrala vlogo žrtvovane anode, kar vodi do katodne zaščite. Rezultati študije so pokazali, da ima Fe-Al plast, izdelana pri $750{ }^{\circ} \mathrm{C}$ boljše protikorozijske lastnosti, ker na njej nastaja trajnejši zaščitni (pasivni) film pri daljšem času potapljanja plasti v umetno morsko vodo.

Ključne besede: Fe-Al plast, elektrokemična impedančna spektroskopija, korozijsko obnašanje, žrtvovana anoda

\section{INTRODUCTION}

$\mathrm{Fe}-\mathrm{Al}$ intermetallic compounds are often used as the traditional engineering materials due to their low density, high-temperature strength, outstanding oxidation and corrosion resistance. ${ }^{1-3}$ In recent years, many studies have been carried out, leading to a lot of progress in the applications of $\mathrm{Fe}-\mathrm{Al}$ as a protective surface layer, prepared with various methods. For instance, M. Emami et al. ${ }^{1}$ researched an aluminized layer fabricated by hot-dip aluminizing, with the phases including $\mathrm{Fe}_{2} \mathrm{Al}_{5}$ and $\mathrm{FeAl}_{3}$. Some other scholars have also made a comprehensive research into plasma aluminizing, slurry aluminizing and mechanical alloying. ${ }^{2-6}$ Moreover, pack aluminizing is a commonly used method for obtaining an $\mathrm{Fe}-\mathrm{Al}$ layer $\mathrm{r}^{7,8}$ as an in-situ chemical vapor deposition (CVD) process, which has the advantages of a simple operation, stable process and good quality. Z. L. Zhan et al. ${ }^{7}$ discussed the microstructure and high-temperature oxidation of an aluminide coating, produced on carbon steel with a combination of surface refinement and pack aluminizing.

*Corresponding author's e-mail:

gchen@njust.edu.cn (Guang Chen)
Just like all the methods mentioned above, individual properties of an $\mathrm{Fe}-\mathrm{Al}$ layer were also researched, specifically the high-temperature oxidation and sulfidation corrosion $^{9-11}$ in addition to wear. ${ }^{12}$ The aqueous corrosion behavior at room temperature of Fe-Al layers made with methods other than pack aluminizing, was also studied. Typically, X. L. Zhu et al. ${ }^{13}$ discussed the corrosion properties of $\mathrm{Fe}-\mathrm{Al}$ layers in the $\mathrm{Na}_{2} \mathrm{~S}$ and $\mathrm{Na}_{2} \mathrm{SO}_{4}+\mathrm{NaCl}$ solutions, fabricated with double-glow plasma surface alloying. An Fe-Al layer has a potential application in the marine environment and electrochemical measurement, particularly with electrochemical impedance spectroscopy (EIS), which is commonly used to characterize the corrosion behavior in artificial seawater. ${ }^{14,15}$

In the initial research, the potentiodynamic polarization curves and weight-loss method were used to characterize the corrosion behavior of an $\mathrm{Fe}-\mathrm{Al}$ layer in artificial seawater, as described in reference. ${ }^{16}$ The aim of this work is to investigate the corrosion behavior of $\mathrm{Fe}-\mathrm{Al}$ layers with the EIS method to verify the previous conclusions. 


\section{EXPERIMENTAL PART}

\subsection{Materials preparation}

The substrates were low-carbon steels (Q235) with the nominal chemical composition shown in Table $\mathbf{1}$. The substrates were aluminized at $650{ }^{\circ} \mathrm{C}$ or $750{ }^{\circ} \mathrm{C}$ for $20 \mathrm{~h}$ after the pretreatment, with the pack-powder mixture of $8 \mathrm{Al}-87 \mathrm{Al}_{2} \mathrm{O}_{3}-5 \mathrm{AlCl}_{3}(w / \%)$. Detailed experimental procedures and results had been described elsewhere. ${ }^{16}$ The preliminary main outcomes were summarized as follows: the content of $\mathrm{Al}$ in the $\mathrm{Fe}-\mathrm{Al}$ layer fabricated at $650{ }^{\circ} \mathrm{C}(73.02 \mathrm{a} / \%)$ is slightly higher than that at $750{ }^{\circ} \mathrm{C}(72.49 \mathrm{a} / \%)$ and both layers include the $\mathrm{Fe}_{2} \mathrm{Al}_{5}$ and $\mathrm{FeAl}_{3}$ phases. It means that the $\mathrm{Fe}-\mathrm{Al}$ layer formed at $750{ }^{\circ} \mathrm{C}$ contained more $\mathrm{Fe}_{2} \mathrm{Al}_{5}$ phase than that formed at $650{ }^{\circ} \mathrm{C}$. Specifically, the experiment included phase testing, cross-sectional morphology and element-content distribution, while further details can be found in reference. $^{16}$

Table 1: Nominal chemical composition of the Q235 low-carbon steel $(w / \%)$

\begin{tabular}{|c|c|}
\hline Composition & Content \\
\hline $\mathrm{C}$ & $0.140-0.220$ \\
\hline $\mathrm{Mn}$ & $0.300-0.650$ \\
\hline $\mathrm{Si}$ & 0.300 \\
\hline $\mathrm{S}$ & $\leq 0.050$ \\
\hline $\mathrm{P}$ & 0.045 \\
\hline $\mathrm{Fe}$ & $\mathrm{Bal}$ \\
\hline
\end{tabular}
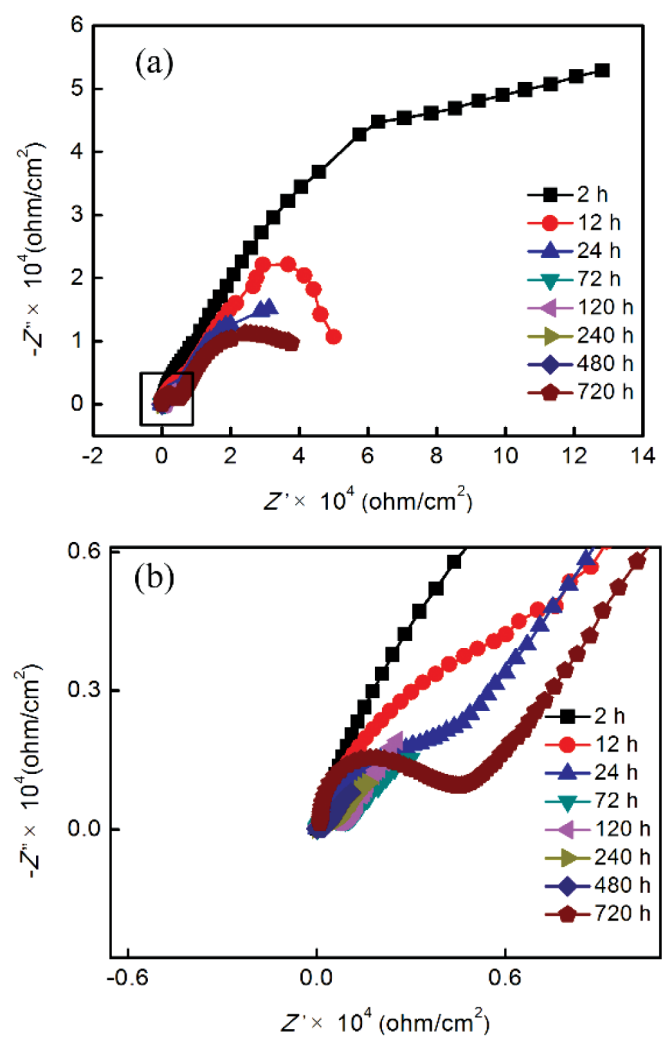

Figure 1: Nyquist plots of the Fe-Al layer fabricated at $650{ }^{\circ} \mathrm{C}$ : a) original image, b) larger image

\subsection{Electrochemical measurements}

The electrochemical measurements were performed with a conventional three-electrode system, using a CHI604D-type (Chenhua, Shanghai, China) electrochemical workstation at room temperature. The samples were embedded in epoxy resin with an exposed area of $1 \mathrm{~cm}^{2}(L \times W)$, used as the working electrode. A saturated calomel electrode (SCE) served as the reference electrode, while the Pt electrode was the counter electrode. The solution for the electrochemical corrosion tests was artificial seawater, whose composition is shown in Table 2 according to GB/T 17848-1999 (China). ${ }^{17}$

Table 2: Chemical composition of artificial seawater $(\mathrm{g} / \mathrm{L})$

\begin{tabular}{|c|c|}
\hline Composition & Content $(\mathrm{g} / \mathrm{L})$ \\
\hline $\mathrm{NaCl}$ & 24.530 \\
\hline $\mathrm{MgCl}_{2} \cdot 6 \mathrm{H}_{2} \mathrm{O}$ & 11.110 \\
\hline $\mathrm{CaCl}_{2} \mathrm{SO}_{4}$ & 4.090 \\
\hline $\mathrm{KCl}$ & 1.160 \\
\hline $\mathrm{NaHCO}_{3}$ & 0.700 \\
\hline $\mathrm{KBr}_{2}$ & 0.200 \\
\hline $\mathrm{SrCl}_{2} \cdot 6 \mathrm{H}_{2} \mathrm{O}$ & 0.100 \\
\hline $\mathrm{NaF}$ & 0.042 \\
\hline $\mathrm{H}_{3} \mathrm{BO}$ & 0.003 \\
\hline & 0.027 \\
\hline
\end{tabular}

Before the electrochemical tests, all the samples were immersed in the electrolyte solution for $30 \mathrm{~min}$. The EIS was carried out at a frequency range of $0.1-100000 \mathrm{~Hz}$ and the amplitude was $5 \mathrm{mV}$. During all the experiments, the samples were immersed in artificial seawater at room temperature for a total of 30 days. After $(2,12,24,72$, $120,240,480$ and 720) h, the samples were tested with the EIS method. The solution was refreshed every seven days during the soaking period. After that, equivalent circuit models were adapted to acquire more information, which was analyzed with the ZSimpWin software, in order to further discuss the corrosion resistance of the aluminized layer.

\section{RESULTS AND DISCUSSION}

\subsection{EIS results}

Figures 1 and $\mathbf{2}$ show typical Nyquist and Bode plots, obtained after the EIS test of the Fe-Al layer fabricated at $650{ }^{\circ} \mathrm{C}$. There are a big capacitive arc in the initial $2 \mathrm{~h}$ (Figure 1a) and arcs for $12 \mathrm{~h}$ and $24 \mathrm{~h}$ (the large image in Figure 1b). The capacitive-arc radius gradually decreases until the 720th h. Thus, it can be inferred that the capacitive arc for the early $2 \mathrm{~h}$ should be the superposition of the other two capacitive arcs, which is also illustrated by the two peaks on the Bode plots (Figure 2b). Two capacitive arcs represent two time constants, which further illustrate two interfaces. To be more specific, one refers to the passive film and electrolyte solution, the other refers to the passive film and aluminized layer surface. A. Ashrafi et al. ${ }^{18}$ studied the passive-film 

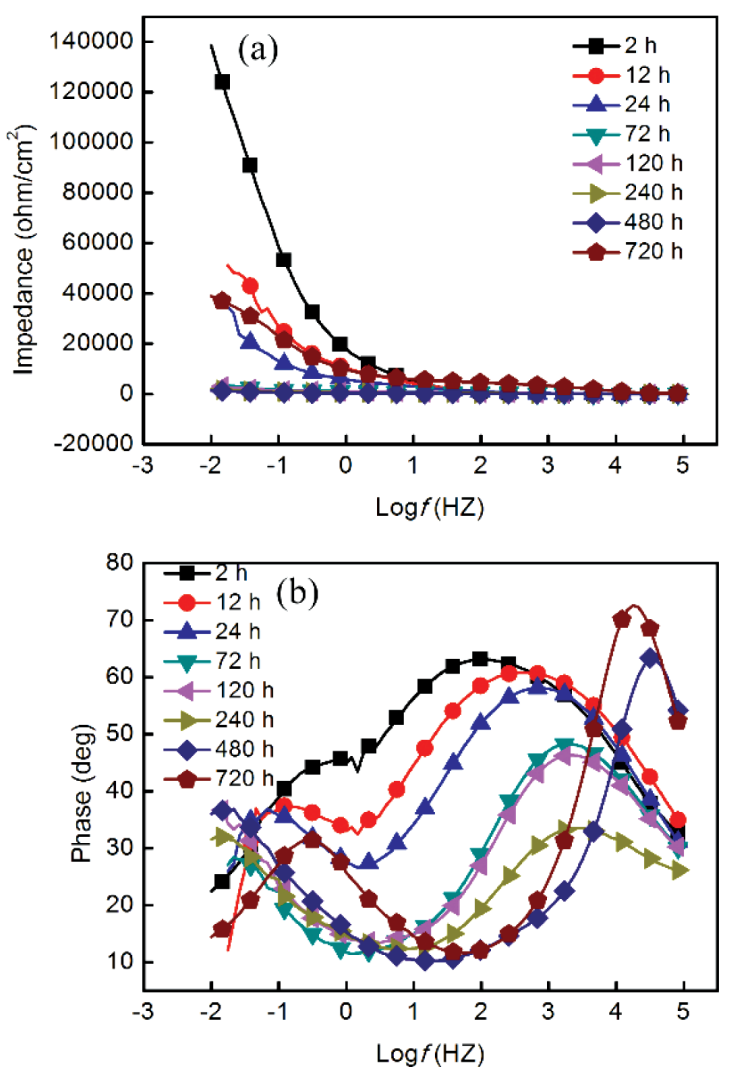

Figure 2: Bode plots of the $\mathrm{Fe}-\mathrm{Al}$ layer fabricated at $650^{\circ} \mathrm{C}$ : a) impedance, b) phase
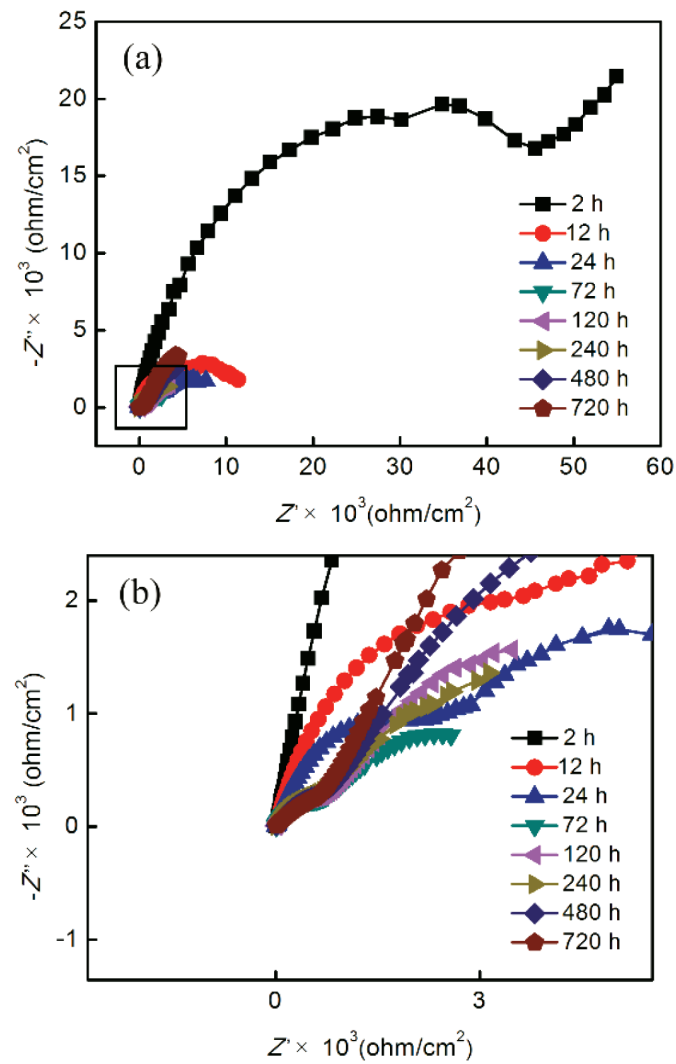

Figure 3: Nyquist plots of the $\mathrm{Fe}-\mathrm{Al}$ layer fabricated at $750{ }^{\circ} \mathrm{C}$ : a) original image, b) larger image formation on mild steel in an oxalic acid solution tested with EIS, and also described the meaning of the two time constants, one being the metal/oxide interface and the other being the oxide/solution interface.

It can also be concluded that the passive-film formation is indicated by the high-frequency region in the Bode plots. A high-frequency region represents a chemical reaction between the original aluminized layer surface and solution. On the contrary, a damage process is related to a low-frequency zone. The impedance values are decreased at first and then increased as shown in Figure 2a. The phase angle is shown in Figure 2b. As a general rule, the larger the phase angle, the more complete is the passive film. On the contrary, the smaller the phase angle, the more broken is the passive film. Generally speaking, the Fe-Al layer surface is unstable during the immersion due to the trend change in the impedance and phase angle.

As shown in Figures 3 and $\mathbf{4}$, the same method was applied to the Fe-Al layer fabricated at $750{ }^{\circ} \mathrm{C}$. The most obvious difference is in the Nyquist plots, which have two arcs during and after the 12th h, as shown in Figure 3a. In addition, the left high-frequency capacitive-arc radiuses are gradually reduced, as shown in Figure $\mathbf{3 b}$, which is caused by the destroyed passive film. The right low-frequency capacitive arc is not obvious after $2 \mathrm{~h}$ because the initial corrosion behavior has not yet fully developed. Later, the low-frequency capacitive arc emerges
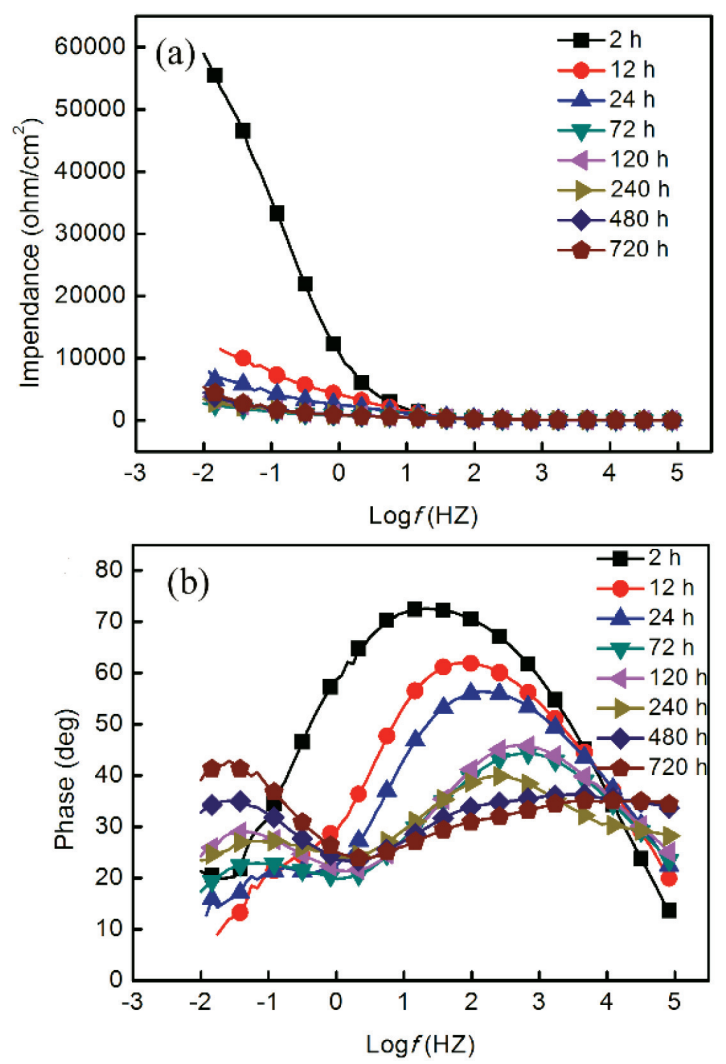

Figure 4: Bode plots of the $\mathrm{Fe}-\mathrm{Al}$ layer fabricated at $750{ }^{\circ} \mathrm{C}$ : a) impedance, b) phase 


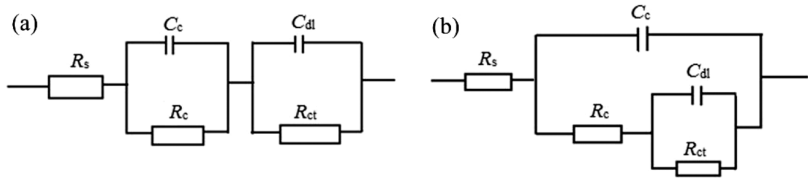

Figure 5: Common equivalent circuit models of two time constants: a) $R(C R)(C R)$, b) $R(C(R(C R)))$

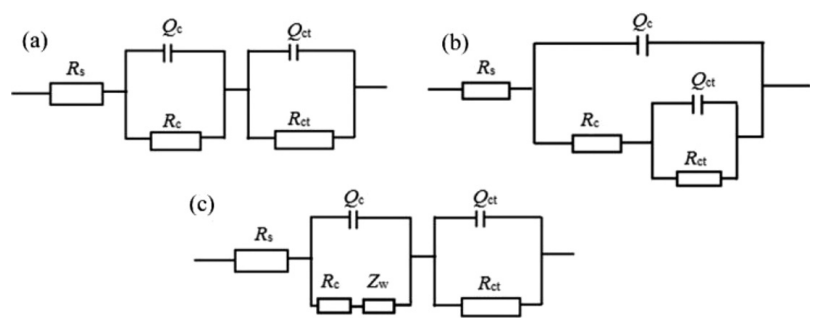

Figure 6: Equivalent-circuit models of the $\mathrm{Fe}-\mathrm{Al}$ layer fabricated at $650{ }^{\circ} \mathrm{C}$ for different immersion times

gradually. At the same time, the two capacitive arcs correspond to the two time constants, two interfaces and two essential chemical reactions.

The impedance values of the Bode plots first decrease and then remain stable in Figure 4a. On the other hand, the phase-angle values at a high frequency gradually descend with the prolonged reaction time in Figure 4b. However, the phase angle at a low frequency is not clear at the beginning, but develops after $12 \mathrm{~h}$. The two peaks still correspond to the two time constants. The reason for the corrosion behavior will be discussed later.

\subsection{Equivalent circuits}

As it is known to all, the EIS results can be simulated with various equivalent circuits and the ones most frequently used are shown in Figure 5, corresponding to the two time constants. As shown in Figure 5a, this model is applied to the electrolyte-solution uniform seeping into the aluminized layer. However, the model from Figure $\mathbf{5 b}$ is suitable for the electrolyte solution seeping into the interface of the passive film and aluminized layer. The charging and discharging of the Fe-Al layer, except for the corroded passive-film, are not affected by the mass-transfer process.

As a matter of fact, the diffusion effect often exists, so the equivalent-circuit models need to be modified,

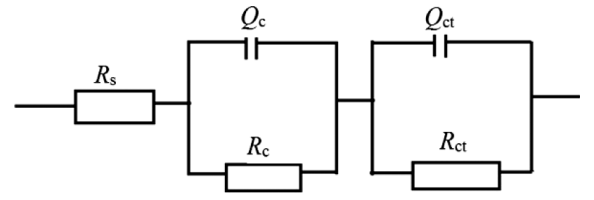

Figure 7: Equivalent-circuit models of the Fe-Al layer fabricated at $750{ }^{\circ} \mathrm{C}$

most clearly replacing $C$ with the constant phase-angle element (CPE) that is $Q$. The adjusted models are shown in Figures 6 and 7. The component symbols represent the following: $R_{\mathrm{s}}$ is the solution resistance, $Q_{\mathrm{c}}$ is the capacitance of the original Fe-Al layer surface, including the passive film and later the corrosion products. $R_{\mathrm{c}}$ is the resistance of the passive film or corrosion products on the Fe-Al layer surface. $Q_{\mathrm{ct}}$ is the new electric double-layer capacitor, contacting the corrosive medium through pores. $R_{\mathrm{ct}}$ is the charge-transfer resistance at the surface and electrolyte interface. $Y_{0}\left(\Omega \cdot \mathrm{cm}^{-2} \cdot \mathrm{s}^{\mathrm{n}}\right)$ and $n$ $(0 \leq n \leq 1)$ are the two parameters that characterize $Q_{\mathrm{ct}}$ and $Q_{\mathrm{c}} . Y_{0}$ represents the base admittance of CPE, while $n$ is the exponent, which can be used as the gauge of surface heterogeneity. ${ }^{19}$ When more corrosion products are formed on the surface, they result in the approximate wireless length of the diffusion path and then the usual Warburg impedance appears. $Z_{\mathrm{w}}$ is the resistance symbol.

The $R(Q R)(Q R)$ model is suitable for etching after $2 \mathrm{~h}$ and $720 \mathrm{~h}$, the $R(Q(R(Q R)))$ model is suitable for the period of $12-72 \mathrm{~h}$, while the $R(Q(R W)(Q R))$ model is suitable for the period of $120-480 \mathrm{~h}$, as shown in Figures $6 \mathbf{a}$ to $\mathbf{6 c}$. In the first two hours, the seawater is infiltrated uniformly. In the period of 12-72 h, the electrolyte solution is in contact with the interface between the passive film and aluminized layer; after the passive film is destroyed, corrosion products appear. The iron and aluminum products affect the corrosion process. Therefore, corrosion is caused by the corrosion-product accumulation, controlled by charge transfer and diffusion between $120 \mathrm{~h}$ and $480 \mathrm{~h}$. However, diffusion is still the main controlling factor. It is clear that the corrosion behavior of the Fe-Al layer fabricated at $650{ }^{\circ} \mathrm{C}$ is controlled by the charge transfer and diffusion. This is also confirmed with the $R_{\mathrm{ct}}$ values from Table 3 . That is to say, the corrosion first increased and then decreased, but increased again. At the same time, the effect of corrosion products

Table 3: EIS parameters of the aluminized layer fabricated at $650{ }^{\circ} \mathrm{C}$ and immersed in seawater for different times

\begin{tabular}{|c|c|c|c|c|c|c|c|c|}
\hline \multirow{2}{*}{ Time (h) } & $R_{\mathrm{S}}$ & \multicolumn{2}{|c|}{$Q_{\mathrm{c}}$} & $R_{\mathrm{c}}$ & $Z_{\mathrm{W}}$ & \multicolumn{2}{c|}{$Q_{\mathrm{ct}}$} & $R_{\mathrm{ct}}$ \\
\cline { 2 - 9 } & $\Omega \cdot \mathrm{cm}^{-2}$ & $Y_{0}\left(\Omega \cdot \mathrm{cm}^{-2} \cdot \mathrm{s}^{\mathrm{n}}\right)$ & $n$ & $\Omega \cdot \mathrm{cm}^{-2}$ & & $Y_{0}\left(\Omega \cdot \mathrm{cm}^{-2} \cdot \mathrm{s}^{\mathrm{n}}\right)$ & $n$ & $\Omega \cdot \mathrm{cm}^{-2}$ \\
\hline 2 & 12.450 & $1.925 \times 10^{-5}$ & 0.6497 & $1.803 \times 10^{5}$ & - & $1.050 \times 10^{-5}$ & 0.9335 & $3.649 \times 10^{3}$ \\
\hline 12 & 10.510 & $9.999 \times 10^{-6}$ & 0.6992 & $1.162 \times 10^{4}$ & - & $4.444 \times 10^{-5}$ & 0.7714 & $5.330 \times 10^{4}$ \\
\hline 24 & 13.000 & $1.088 \times 10^{-5}$ & 0.6916 & $4.854 \times 10^{3}$ & - & $1.041 \times 10^{-4}$ & 0.6358 & $5.346 \times 10^{4}$ \\
\hline 72 & 12.020 & $1.878 \times 10^{-5}$ & 0.6481 & $8.554 \times 10^{2}$ & - & $1.407 \times 10^{-3}$ & 0.4859 & $1.785 \times 10^{4}$ \\
\hline 120 & 9.285 & $7.793 \times 10^{-6}$ & 0.8759 & $1.888 \times 10^{2}$ & $1.479 \times 10^{-3}$ & $8.350 \times 10^{-5}$ & 0.5265 & $5.629 \times 10^{2}$ \\
\hline 240 & 7.542 & $4.685 \times 10^{-4}$ & 0.3479 & $4.159 \times 10^{2}$ & $1.844 \times 10^{-3}$ & $2.273 \times 10^{-5}$ & 0.7390 & $1.509 \times 10^{2}$ \\
\hline 480 & 4.360 & $6.363 \times 10^{-5}$ & 0.6343 & $1.486 \times 10^{2}$ & $3.356 \times 10^{-3}$ & $2.463 \times 10^{-7}$ & 0.9210 & 82.49 \\
\hline 720 & 64.770 & $3.337 \times 10^{-8}$ & 0.9356 & $3.790 \times 10^{3}$ & - & $4.905 \times 10^{-5}$ & 0.5259 & $5.4070 \times 10^{4}$ \\
\hline
\end{tabular}


Table 4: EIS parameters of the aluminized layer fabricated at $750{ }^{\circ} \mathrm{C}$ and immersed in seawater for different times

\begin{tabular}{|c|c|c|c|c|c|c|c|}
\hline \multirow{2}{*}{ Time (h) } & $R_{\mathrm{S}}$ & \multicolumn{2}{|c|}{$Q_{\mathrm{c}}$} & $R_{\mathrm{c}}$ & \multicolumn{2}{c|}{$Q_{\mathrm{ct}}$} & $R_{\mathrm{ct}}$ \\
\cline { 2 - 8 } & $\Omega \mathrm{cm}^{-2}$ & $Y_{0}\left(\Omega \mathrm{cm}^{-2} \cdot \mathrm{s}^{\mathrm{n}}\right)$ & $n$ & $\Omega \mathrm{cm}^{-2}$ & $Y_{0}\left(\Omega \mathrm{cm}^{-2} \cdot \mathrm{s}^{\mathrm{n}}\right)$ & $n$ & $\Omega \mathrm{cm}^{-2}$ \\
\hline 2 & 6.889 & $1.070 \times 10^{-4}$ & 0.6631 & $6.2530 \times 10^{4}$ & $2.181 \times 10^{-5}$ & 0.8819 & $2.8440 \times 10^{4}$ \\
\hline 12 & 6.435 & $2.620 \times 10^{-5}$ & 0.8868 & $2.213 \times 10^{3}$ & $1.342 \times 10^{-4}$ & 0.5842 & $1.0800 \times 10^{4}$ \\
\hline 24 & 5.861 & $3.386 \times 10^{-5}$ & 0.7938 & $1.585 \times 10^{3}$ & $3.167 \times 10^{-4}$ & 0.5051 & $8.551 \times 10^{3}$ \\
\hline 72 & 6.684 & $1.212 \times 10^{-4}$ & 0.5680 & $7.165 \times 10^{2}$ & $1.317 \times 10^{-3}$ & 0.5976 & $3.149 \times 10^{3}$ \\
\hline 120 & 5.358 & $8.557 \times 10^{-4}$ & 0.4188 & $3.1540 \times 10^{4}$ & $6.909 \times 10^{-5}$ & 0.6848 & $4.457 \times 10^{2}$ \\
\hline 240 & 3.528 & $7.251 \times 10^{-4}$ & 0.3662 & $1.7410 \times 10^{4}$ & $9.628 \times 10^{-5}$ & 0.7698 & $2.264 \times 10^{2}$ \\
\hline 480 & 2.828 & $1.179 \times 10^{-3}$ & 0.6845 & $8.833 \times 10^{3}$ & $2.220 \times 10^{-4}$ & 0.4411 & $1.089 \times 10^{3}$ \\
\hline 720 & 1.211 & $2.547 \times 10^{-4}$ & 0.4157 & $9.496 \times 10^{2}$ & $1.022 \times 10^{-3}$ & 0.6946 & $1.4600 \times 10^{4}$ \\
\hline
\end{tabular}

on the corrosion property is illustrated with the Warburg impedance $Z_{\mathrm{w}}$.

The updated equivalent-circuit model of the $\mathrm{Fe}-\mathrm{Al}$ layer fabricated at $750{ }^{\circ} \mathrm{C}$ is shown in Figure 7. The symbols of the components were described above. The $R(Q R)(Q R)$ model also indicates that the seawater infiltrated uniformly. According to the fitting results, the Warburg impedance is not observed, so the corrosion products had no influence on the corrosion, and the whole immersion was controlled by the charge transfer. The fitted data is shown in Table 4. It is different from the data obtained earlier. The value of $R_{\mathrm{ct}}$ reflects the corrosion resistance. That is, the larger the $R_{\mathrm{ct}}$, the better is the corrosion resistance.

\subsection{Corrosion mechanism}

As stated in reference, ${ }^{16}$ pitting corrosion is found with two methods. One is creating a polarization curve, the other is determining the weight loss. However, the effect of the corrosion products on the erosion process is not described. Based on the EIS results, the corrosion mechanism can be obtained as shown in Figure 8.
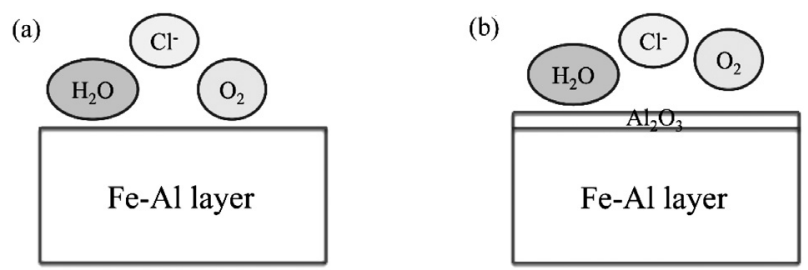

(c)
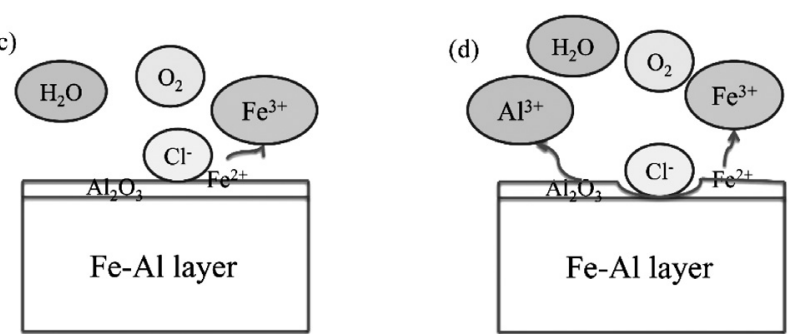

Figure 8: Schematic diagram of the corrosion mechanism of the $\mathrm{Fe}-\mathrm{Al}$ layer in seawater: a) Fe-Al layer in touch with seawater, b) $\mathrm{Al}_{2} \mathrm{O}_{3}$ passive film formed, c) chlorine ion reacting with the passive film and the iron ions produced, d) etching pits emerged
It is generally known that aluminum exhibits a strong corrosion activity. When $\mathrm{Al}$ contacts the oxygen atoms in water, the alumina passive film immediately becomes oxidized (Figures 8a and 8b). In seawater, chloride ion, that is, $\mathrm{Cl}^{-}$is the most corrosive. However, the passive film is destroyed when it meets $\mathrm{Cl}^{-}$. Meanwhile, the iron atoms go through a similar process, maintaining the charge stable (Figure 8c). Finally, pitting arises (Figure 8d). In this way, the aluminized layer can be used as the sacrificial anode, providing for the cathodic protection of low-carbon steel. The main chemical reactions for the passive film are as follows:

$$
\begin{gathered}
\mathrm{Al}+\mathrm{H}_{2} \mathrm{O} \rightarrow \mathrm{AlOH}+\mathrm{H}^{+}+\mathrm{e}^{-} \\
\mathrm{AlOH}+\mathrm{H}_{2} \mathrm{O} \rightarrow \mathrm{Al}(\mathrm{OH})_{2}+\mathrm{H}^{+}+\mathrm{e}^{-} \\
\mathrm{Al}(\mathrm{OH})_{2} \rightarrow \mathrm{AlOOH}+\mathrm{H}^{+}+\mathrm{e}^{-}
\end{gathered}
$$

When the $\mathrm{Cl}^{-}$ions begin to surround and dissolve metal ions, the typical reactions are as follows:

$$
\begin{gathered}
\mathrm{AlOH}+\mathrm{Cl}^{-} \rightarrow \mathrm{AlOHCl}+\mathrm{e}^{-} \\
\mathrm{AlOHCl}+\mathrm{Cl}^{-} \rightarrow \mathrm{AlOHCl}_{2}+\mathrm{e}^{-}
\end{gathered}
$$

As described above, after the 120-h immersion, the aluminized layer fabricated at $650{ }^{\circ} \mathrm{C}$ is influenced by the corrosion products, as illustrated with the Warburg impedance $Z_{\mathrm{w}}$. The self-sealing effect caused by the corrosion products leads to an increased resistance. Within this process, there is a synergistic effect of the passive film and corrosion products on the aluminized-layer surface. The total erosion is affected by the charge transfer and diffusion. However, the products have no obvious effect on the corrosion resistance of the layer fabricated at $750{ }^{\circ} \mathrm{C}$ and the whole erosion is protected by the passive film. In addition, the charge transfer is the dominating process.

From the above data, it can be seen that the $\mathrm{Fe}-\mathrm{Al}$ layer can improve the corrosion resistance of a steel substrate. The layer prepared at $750{ }^{\circ} \mathrm{C}$ exhibits a better performance, which is consistent with the results acquired from other references. ${ }^{16}$ This may be due to its strong ability to form a passive film, namely alumina. 


\section{CONCLUSIONS}

(1) There are two capacitive arcs obtained with the Nyquist and Bode plots of the two Fe-Al layers, representing two reactions; one is the formation of a passive film, the other is the destruction of the passive film.

(2) The layer fabricated at $750{ }^{\circ} \mathrm{C}$ exhibits a better corrosion resistance. This is due to the alumina passive film functioning as the sacrificial anode, while the products have no effect on the erosion process.

\section{Acknowledgement}

This research was funded by the National Science Foundation of China (Nos. 51571117, 51731006, 51771093 and 91860104) and the High-Level Introduction of Talent Research Start-Up Fund of North China University of Water Resources and Electric Power (No. 4001/40680).

\section{REFERENCES}

${ }^{1}$ M. Emami, H. R. Shahverdi, S. Hayashi, M. J. Torkamany, A combined hot dip aluminizing/laser alloying treatment to produce iron-rich aluminides on alloy steel, Metall. Mater. Trans. A., 44 (2013), 3176-3184, doi:10.1007/s11661-013-1666-2

${ }^{2}$ A. R. Rastkar, N. Rezvani, The effects of processing time on the microstructure and composition of plasma pack aluminized and oxidized surface layers on low carbon steel, Metall. Mater. Trans. A., 46 (2015), 4132-4142, doi:10.1007/s11661-015-3034-x

${ }^{3}$ A. Soleimani Dorcheh, M. C. Galetz, Slurry aluminizing: A solution for molten nitrate salt corrosion in concentrated solar power plants, Sol. Energ. Mat. Sol. C., 146 (2016), 8-15, doi:10.1016/j.solmat. 2015.11.024

${ }^{4}$ A. Canakci, T. Varol, F. Erdemir, S. Ozkaya, H. Mindivan, Microstructure and properties of $\mathrm{Fe}-\mathrm{Al}$ intermetallic coatings on the low carbon steel synthesized by mechanical alloying, Int. J. Adv. Manuf. Tech., 73 (2014), 849-858, doi:10.1007/s00170-014-5851-2

${ }^{5}$ H. R. Karimi Zarchi, M. Soltanieh, M. R. Aboutalebi, X. Guo, Kinetic study on $\mathrm{NaF}$-activated pack-aluminizing of pure titanium at 950-1100 ${ }^{\circ} \mathrm{C}$, T. Nonferr. Metal. Soc., 24 (2014) 6, 1959-1968, doi:10.1016/S1003-6326(14)63277-5

${ }^{6}$ A. R. Rastkar, P. Parseh, N. Darvishnia, S. M. M Hadavi, Microstructural evolution and hardness of $\mathrm{TiAl}_{3}$ and $\mathrm{TiAl}_{2}$ phases on Ti-45Al-2Nb-2Mn-1B by plasma pack aluminizing, Appl. Surf. Sci., 276 (2013), 112-119, doi:10.1016/j.apsusc.2013.03.043
${ }^{7}$ Z. L. Zhan, Z. Liu, J. X. Liu, L. Li, Z. Li, P. B. Liao, Microstructure and high temperature corrosion behaviors of aluminide coatings by low-temperature pack aluminizing process, Appl. Surf. Sci., 256 (2010) 12, 3874-3879, doi:10.1016/j.apsusc.2010.01.043

${ }^{8}$ Z. D. Xiang, P. K. Datta, Effects of pack composition on the formation of aluminide coatings on alloy steels at $650{ }^{\circ} \mathrm{C}$, J. Mater. Sci., 40 (2005), 1959-1966, doi:10.1007/s10853-005-1217-3

${ }^{9}$ A. Nishimoto, K. Akamatsu, Microstructure and oxidation resistance of $\mathrm{Fe}_{3} \mathrm{Al}$ coatings on austenitic stainless steel by spark plasma sintering, Plasma Process. Polym., 6 (2009), S941-S943, doi:10.1002/ppap.200932407

${ }^{10}$ M. Emami, S. M. M Hadavi, S. Hayashi, H. R. Shahverdi, High temperature performance of an FeAl laser coated 9Cr1Mo steel, Oxid. Met., 80 (2013), 437-451, doi:10.1007/s11085-013-9415-X

${ }^{11}$ D. R. Yan, Y. Yang, Y. C. Dong, X. Chen, L. Wang, Phase transitions of plasma sprayed Fe-Al intermetallic coating during corrosion in molten zinc at $640{ }^{\circ} \mathrm{C}$, Intermetallics, 22 (2012), 160-165, doi:10.1016/j.intermet.2011.10.017

${ }^{12}$ Y. Zhou, S. Q. Wang, B. G. Zhang, Q. Y. Zhang, D. Q. Zhou, Relation between tribolayers and wear behavior during dry sliding of Fe-Al hot-dipped coating, Tribol. T., 60 (2017) 6, 1078-1087, doi:10.1080/10402004.2016.1259436

${ }^{13}$ X. L. Zhu, Z. J. Yao, X. D. Gu, W. Cong, P. Z. Zhang, Microstructure and corrosion resistance of Fe-Al intermetallic coating on 45 steel synthesized by double glow plasma surface alloying technology, T. Nonferr. Metal. Soc., 19 (2009) 1, 143-148, doi:10.1016/s10036326(08) 60242-3

${ }^{14}$ A. Canakci, T. Varol, F. Erdemir, S. Ozkaya, H. Mindivan, Microstructure and properties of Fe-Al intermetallic coatings on the low carbon steel synthesized by mechanical alloying, Int. J. Adv. Manuf. Tech., 73 (2014), 849-858, doi:10.1007/s00170-014-5851-2

${ }^{15}$ A. H. Seikh, A. Sarkar, J. K. Singh, S. M. A. Khan Mohammed, N. Alharthi, M. Ghosh, Corrosion Characteristics of Copper-Added Austempered Gray Cast Iron (AGCI), Materials, 12 (2019) 3, 503, doi:10.3390/ma12030503

${ }^{16}$ N. N. Li, M. Z. Wang, Y. S. Li, G. Chen, P. Li, Corrosion behavior of $\mathrm{Fe}-\mathrm{Al}$ coatings fabricated by pack aluminizing method, Acta Metall. Sin., 29 (2016) 9, 813-819, doi:10.1007/s 40195-016-0455-5

${ }^{17}$ Test Methods for Electrochemical Properties of Sacrificial Anodes, GB/T 17848-1999 (in Chinese)

${ }^{18}$ A. Ashrafi, M. A. Golozar, S. Mallakpour, EIS investigation of passive film formation on mild steel in oxalic acid solution, J. Appl. Electrochem., 38 (2008), 225-229, doi:10.1007/s10800-007-9429-7

${ }^{19}$ N. Ahledel, R. Schulz, M. Gariepy, H. Hermawan, H. Alamdari, Electrochemical corrosion behavior of $\mathrm{Fe}_{3} \mathrm{Al} / \mathrm{TiC}$ and $\mathrm{Fe}_{3} \mathrm{Al}-\mathrm{Cr} / \mathrm{TiC}$ coatings prepared by $\mathrm{HVOF}$ in $\mathrm{NaCl}$ solution, Metals, 9 (2019) 4, 437, doi:10.3390/met 9040437 